\title{
Passive Bilingualism in the Iberian Peninsula
}

Bilingüismo pasivo en la península ibérica

Bilinguismo passivo na Península Ibérica

Jan Mrva* iD orcid.org/0000-0002-6124-475x

Artículo de investigación

Revista Colombiana de Educación, N.ㄱ 75. Segundo semestre de 2018, Bogotá, Colombia.

doi: 10.17227/rce.num75-8109

Para citar este artículo: Mrva, J. (2018). Passive Bilingualism Within the Iberian Peninsula. Revista Colombiana de Educación, 75, 215-241.

\section{(c) (i) (5)}




\begin{abstract}
The purpose of this article is to describe passive bilingualism and the sociolinguistic situation in the Iberian Peninsula from the current perspective and to analyze the degree of passive bilingualism in this environment. In the first part, we introduce the reader to the problematic of passive bilingualism, and we attempt to define it using the contemporary theories made mainly in the field of Germanic languages. The practical part is dedicated to describing the hypothesis and the methodology that we applied when creating the questionnaire. In this part, we also include the demographic data of the respondents who completed the survey. Next is the analysis of the linguistic material, where we analyze: the number of correct and incorrect answers and the determination of success in different parts of the questionnaire; the possible causes of the wrong answer; the general level of passive comprehension in Galician, Catalan, Basque and Portuguese. In the discussion, we summarize, above all, the most important results of the analysis. Finally, we report on the pedagogical possibilities of the used languages.
\end{abstract}

\section{Keywords}

passive bilingualism; Iberian Peninsula; Germanic languages

\title{
Resumen
}

\section{Palabras clave}

bilingüismo pasivo; península

ibérica; lenguas germánicas
El objetivo de este artículo ha sido describir el bilingüismo pasivo y la situación sociolingüística en la península ibérica desde la perspectiva actual y, a continuación, analizar el grado del bilingüismo pasivo en este ambiente. En la primera parte introducimos al lector a la problemática del bilingüismo pasivo e intentamos definirlo de acuerdo con las teorías contemporáneas hechas en el campo de lenguas germánicas. La parte práctica se dedica a la descripción de la hipótesis y la metodología que aplicamos al crear el cuestionario. En esta parte también incluimos los datos demográficos de los respondientes que completaron el cuestionario. Sigue el análisis del material lingüístico como tal, en el que analizamos: el número de respuestas correctas e incorrectas y a continuación, la determinación del éxito en diferentes partes del cuestionario; las causas de las respuesta incorrectas; el nivel general de la comprensión pasiva en gallego, catalán, euskera y portugués. En la discusión resumimos, sobre todo, los resultados más importantes del análisis. Por último informamos sobre las posibilidades pedagógicas de las lenguas usadas.

\section{Resumo}

O propósito deste artigo é descrever o bilinguismo passivo e a situação sociolinguística na península Ibérica desde a perspectiva atual y analisar neste ambiente o grau de bilinguismo passivo. Na primeira parte, introduzimos ao leitor a problemática do bilinguismo passivo e procuramos defini-la utilizando teorias contemporâneas estabelecidas principalmente no campo das línguas germânicas. A parte prática está dedicada à descrição da hipótese e a metodologia aplicada ao criar o questionário. Nesta parte, além disso, in cluímos os dados demográficos dos sujeitos que completaram a enquete. Em seguida é apresentada a análise do material linguístico que inclui: o número de respostas corretas e incorretas e a determinação do sucesso em diversas partes do questionário; as possíveis causas das respostas erradas; o nível geral de compreensão passiva do galego, catalão, basco e português. Na discussão, resumimos os resultados mais importantes da análise Finalmente, informamos sobre as possibilidades pedagógicas das línguas utilizadas.

\section{Palavras-chave}

bilinguismo passivo; península Ibérica; línguas germânicas 


\section{Introduction}

Authors such as Grosjean and Li (2013), Morgensternová, Šulová, and Schöll (2011) and Calvet (1993) started the discussion about bilingual competence by presenting numbers directly related to the current world language reality: approximately six thousand languages in about two hundred sovereign states. Mathematically speaking, there are thirty languages for each of the two hundred countries. However, the result is not consistent with the current situation. In fact, the idea of such geographical multilingual units, especially in contemporary Europe, is mostly unrealistic. Taking this into account, we can say with certainty that bilingualism is not only a current, modern and highly studied phenomenon, but also widespread.

In this regard, we can define a seemingly endless number of bilingual environments around the world. Each of these territories is characterized by the languages in contact, which are used in everyday communication by its inhabitants. For example, a Czech language environment, which is officially represented by Czech, could be described as profoundly monolingual. However, it was influenced by German and later by Russian (the languages of states that were once politically stronger). Moreover, we cannot overlook the role of other languages like Polish or Slovak the languages of neighboring states) and Vietnamese or Romani (languages of minorities). As a result, we are talking about six languages that more or less influenced the Czech language and have been in contact with it. Still, it is Spain (which is unambiguously multilingual at first glance) will be the main focus of this article, and not the Czech Republic.

Although Spanish is the most widespread language (also referred to as "Castilian"), Catalan (Catalonia, Balearic Islands, Valencian Community), Basque (Basque Country), and Galician (Galicia) play an important role in the respective autonomous regions. As for the exclusive status of the official language and the geographical proximity, Portuguese is the most similar to Castilian. However, the Spanish linguistic and cultural identity was formed by other Romance languages (French, Italian) and, of course, Arabic. In the end, we can conclude that there are more or less eight languages with which Castilian is or was in contact with. The question, however, is how comprehensible they are for the present inhabitants of the Iberian Peninsula and how Spaniards understand it without ever learning them before, and how they could be used for teaching purposes; that is the purpose of this research. 


\section{Theoretical Background}

Even before defining the term passive or, in other words, receptive bilingualism, we believe it is necessary to stress on the fact that professional literature in this field of study is not too plentiful and that, to date, only limited attention has been devoted to this topic. However, such focus is also significantly limited to more specifically defined linguistic areas, especially the Germanic countries (Scandinavia, Germany, and the Netherlands). As for Hispanic countries, there has been no research on passive bilingualism in the Iberian Peninsula, and the only investigated area is in Latin America, especially in the contact regions at the Uruguayan-Brazilian border, which complicates the exact placement of the subject under discussion into the particular context of the Iberian Peninsula.

As outlined above, passive bilingualism is synonymous with receptive bilingualism, that is, for language competence, for which there are significant difficulties in using or expressing the second language. Passive or receptive bilingual speakers are more likely to rely on the L1 knowledge and, based on their limited knowledge of the L2, conclude with possible interpretations of a conversation. Grosjean (2010) questioned the passive-receptive pair itself, arguing that passive bilingualism does not exist, since many kinds of cognitive processes are triggered by language interaction of any kind. Thus, this excludes any passivity of human perception. In the following paragraphs, we will only express this type of bilingualism as receptive and later justify our usage of the attribute passive.

Historically speaking, receptive bilingualism represented a natural state of interaction between two different languages and was not unusual: its deliberate suppression began about 200 years ago during the rise of national states and hence national identities (Rindler-Schjerve \& Vetter, 2007). One of the pillars of nation-state formation was and still is a language that represents national literature and traditions, the founding myth, and the idea of a unified and pure community altogether in timeless perception (the five main elements of the nation according to Hall, 2006, pp. 52-56). In this "artificially created community," any presence of a heterogeneous language was undesirable. Those who defined themselves as other than monolingual were condemned and stigmatized by the rest of society. Standardization can also be described as the loss of contact with varieties, dialects and language interaction. However, productive bilingualism and receptive bilingualism are entirely different (see Table 1). 
Table 1. Comparison of receptive and productive multilingualism

\begin{tabular}{|c|c|}
\hline Receptive Multilingualism & Productive Multilingualism \\
\hline Predominantly for informal communication & Both for formal and informal communication \\
\hline $\begin{array}{l}\text { Purpose-oriented, no (productive) acquisition } \\
\text { of the target language is intended }\end{array}$ & $\begin{array}{l}\text { Function-oriented (with reference } \\
\text { to persons, topics, or domains) }\end{array}$ \\
\hline $\begin{array}{l}\text { Face-to-face communication, especially } \\
\text { in diglossic trading situations and } \\
\text { other business contacts may occur }\end{array}$ & $\begin{array}{l}\text { No restrictions in principle but a } \\
\text { distribution of the language involved }\end{array}$ \\
\hline $\begin{array}{l}\text { Establishing communication at any price, } \\
\text { frequent ad hoc-accommodations, no rules }\end{array}$ & $\begin{array}{l}\text { Person-, topic-, or domain-related language } \\
\text { use (including code-switching, if appropriate) }\end{array}$ \\
\hline Highly context- and addressee-dependent & $\begin{array}{l}\text { Low mandatory context or } \\
\text { addressee dependence }\end{array}$ \\
\hline $\begin{array}{l}\text { Emphasis on communication exchange } \\
\text { and efficiency in interaction }\end{array}$ & $\begin{array}{l}\text { All linguistic functions are available (if not } \\
\text { restricted due to domains or functions) }\end{array}$ \\
\hline $\begin{array}{l}\text { Informal but pragmatically controlled } \\
\text { learning by listening and speaking where no } \\
\text { grammatical norms have to be observed }\end{array}$ & $\begin{array}{l}\text { All kinds of natural-language acquisition and } \\
\text { L2 learning, especially for the acquisition of } \\
\text { a lingua franca (e.g., Latin or Low German) }\end{array}$ \\
\hline $\begin{array}{l}\text { Dominance of pragmatics and } \\
\text { the situational context }\end{array}$ & $\begin{array}{l}\text { Dominance of linguistic awareness } \\
\text { with respect to domains, styles, norms, } \\
\text { and grammatical correctness }\end{array}$ \\
\hline $\begin{array}{l}\text { Includes the possibility to become } \\
\text { a (fluent) speaker of the target } \\
\text { language; may gradually include } \\
\text { occasional (lexical) code switching }\end{array}$ & $\begin{array}{l}\text { Language use may be restricted to } \\
\text { functional distribution; therefore, } \\
\text { no necessity for a full linguistic } \\
\text { competence in all languages spoken }\end{array}$ \\
\hline
\end{tabular}

Source: Braunmüller (2007, p. 30).

If we summarize Braumüller's findings, we can conclude that receptive bilingualism is an informal communication that emphasizes the exchange of information at any cost. This communication is based on a great deal of knowledge of pragmatic practices and the situational context, while ignoring the other language components.

Speakers are introducing mutual accommodation agreements that simplify the understanding of both parties, for example, when dealing with a difficult topic or a complicated situation. Zeevaert and Thije (2007, p. 4) set out two options: solving a problem that is based on slowing down the manner of speech, more precise pronunciation, repetition, and reformulation, or employment of a so-called "let it pass" strategy. This implies that, in most cases, receptive bilingualism is the result of an agreement between the two parties involved and that only occurs randomly and spontaneously in a few cases (Braunmüller \& Zeevaert, as cited in Ribbert \& Thije, 2007, p. 78).

The arbitrariness of this type of communication can be gradual and consequently lead to productive competence in the L2, as well as to code-switching. 


\section{Receptive bilingualism and semi-communication}

House and Rehbein (2004, p. 3) claim that the typological proximity of languages sets the conditions under which speakers can easily acquire receptive knowledge of a close language, or, in a case of a distant language, cannot acquire such knowledge at all. This criterion makes it possible to distinguish between receptive bilingualism and semi-communication.

Zeevaert (2007) introduces the following definitions, bearing in mind the typological proximity of languages:

Receptive bilingualism: A reasonable option of communication between languages that are unrelated or only remotely related - under the condition that all speakers involved are familiar with both languages, and provided that the speakers have only a passive competence at their disposal [...] or that the interlocutors prefer to use their own mother tongue in spite of an available active competence [...]. Receptive multilingualism thus provides the opportunity to avoid linguistic discrimination in officially multilingual countries such as Switzerland or Belgium.

Semi-communication: The mutual understanding of speakers of closely related languages. [...] Speakers are able to understand the language of their interlocutor due to the genetic proximity of the two languages and the resulting large typological similarity. (Zeevaert, 2007, pp. 105-106).

Kloss's (1967) divisions on the so-called Abstand and Ausbau languages appear in older studies. Abstand languages are languages that are not typologically close and therefore do not show signs of mutual comprehension. Ausbau languages are ones that can be comprehensible to members of neighboring language communities. Thus, on an European semi-communication scale, the following languages can be pointed out: Scandinavian languages, namely Danish, Swedish, Norwegian (Haugen, 1966, p. 153), West Slavonic Languages, namely Czech and Slovak (Budovicová, 1987), and, last but not least, all the official and co-official languages of the Iberian Peninsula except the Basque language, since it is not typologically close to any Indo-European language. Hence, it falls into the category of Abstand languages and less possible receptive communication situation.

For a more thorough definition of receptive bilingualism and semi-communication, we include Zeevaert's (2007) explanation in Table 2 below: 
Table 2. Comparison of receptive bilingualism and semi-communication

\begin{tabular}{|c|c|c|c|}
\hline & $\begin{array}{c}\text { A is able to } \\
\text { understand } L 1 \\
\text { of } B, B \text { is able to } \\
\text { understand } L 1 \text { of } A\end{array}$ & $\begin{array}{c}\text { A is able to } \\
\text { understand } L 1 \\
\text { of } B, B \text { is able to } \\
\text { understand } L 2 \text { of } A\end{array}$ & $\begin{array}{c}\text { A is able to } \\
\text { understand } L 2 \\
\text { of } B, B \text { is able to } \\
\text { understand } L 2 \text { of } A\end{array}$ \\
\hline $\begin{array}{c}\text { because the } \\
\text { languages } \\
\text { are closely related } \\
\text { (mutually intelligible) }\end{array}$ & $\begin{array}{c}\text { semicommunication } \\
\text { (Haugen, 1996) }\end{array}$ & $\begin{array}{l}\text { secondary speech } \\
\text { community } \\
\text { (Dahlstedt, 197l) }\end{array}$ & $\begin{array}{l}\text { peripheral speech } \\
\text { community } \\
\text { (Börestam, 2001) }\end{array}$ \\
\hline $\begin{array}{l}\text { because the } \\
\text { languages are } \\
\text { related (mutually } \\
\text { unintelligible) and A } \\
\text { and } B \text { have acquired } \\
\text { receptive skills }\end{array}$ & $\begin{array}{l}\text { adjoining languages } \\
\text { (Kloss, 1929) }\end{array}$ & $\begin{array}{c}\text { special case of } \\
\text { intercomprehension }\end{array}$ & $\begin{array}{l}\text { Intercomprehension } \\
\text { (cf., Meissner, 2004) }\end{array}$ \\
\hline $\begin{array}{l}\text { because the } \\
\text { languages are } \\
\text { not or not closely } \\
\text { related (mutually } \\
\text { unintelligible) and A } \\
\text { and B have acquired } \\
\text { receptive skills }\end{array}$ & $\begin{array}{l}\text { polyglot dialogue } \\
\text { (Augustin, 1997) }\end{array}$ & $\begin{array}{l}\text { special case of } \\
\text { polyglot dialogue }\end{array}$ & $\begin{array}{c}\text { receptive } \\
\text { multilingualism (cf., } \\
\text { Hansen, 1987) }\end{array}$ \\
\hline
\end{tabular}

Source: Zeevaert (2007, p. 109).

Before presenting the research itself, we would like to specify the terminology used, specifically the use of the adjective passive when referring to passive-receptive bilingualism. The research we conducted did not involve communication, but one-way passive bilingualism, since participants were not expected to have any knowledge of the L2. We also gave no space for any information exchange in a communicational sequence, which is crucial for the assessment of receptive bilingualism. In other words, for our research, it was important to take into consideration only the monolingual competence with the Castilian language as the L1 and, later, to demonstrate the degree of passive comprehension using passive linguistic competences, namely reading and listening. Galician, Catalan, Basque and Portuguese represented the L2.

\section{Research Intent and Hypothesis}

The subject of the study is to evaluate a questionnaire in order to answer the research question: whether the monolingual Spanish speakers are able to passively understand other official and co-official languages of the Iberian Peninsula. For a better understanding of the language situation in the context set by us, we will also list the four considered language units from the most to the least understandable, and also according to the results of the questionnaire. The expected results are as follows: 
1. Galician (reading, listening)

2. Catalan (reading, listening), Portuguese (reading)

3. Portuguese (listening)

4. Basque (reading, listening)

5. Basque (listening)

The resulting degree of understanding depends mainly on the typological similarity that the isolated Basque does not fully meet, and therefore we also evaluated it as the least comprehensible for any monolingual Spanish speaker. As for the other languages, Galician, Catalan, and Portuguese all fall into the Romance linguistic group. The exact distribution based on available linguistic descriptive information is, in our view, impossible, because it completely suppresses the subjective language skills of the speakers that are ultimately crucial and which we are fully aware of. However, from a purely linguistic point of view, we assume that the most comprehensible will be the written and spoken Galician, which, in terms of phonetic, morphological and lexical features, bears a large resemblance to Castilian. We consider the written and spoken Catalan and Portuguese to be less similar, however, much more present in everyday life: A significant part of the monolingual population spends holidays in the Catalan or Valencian coast or in Portugal, where languages come in contact. Also, Portuguese is the only official language of another political entity, and Catalan is currently the subject of continuous political discussions and debates. Lastly, we consider spoken Portuguese as the least understandable right before the Basque, due to the palatalization of the implosive /s/ and /z/. These changes are relatively recent (since the $19^{\text {th }}$ century), as Hricsina (2015, p. 166) states, and sharply distinguished Portuguese from Castilian.

\section{Methodology}

As previously stated, there are very few research projects that would be devoted exclusively to passive bilingualism; the vast majority of them were conducted in the area of Germanic languages, primarily German and Dutch. Researchers who focus on the subject use both qualitative and quantitative research methods.

Due to the extent and complexity of the study, we decided to use the quantitative method of our questionnaire, and the QuestionPro web page was chosen to create and distribute the questionnaire. The project was assigned its own customized Internet address, available at https:// bilinguismopasivo.questionpro.com. It was launched on Thursday, April 
6, 2017 and closed on Tuesday, June 6, 2017; it was, therefore, freely accessible for two months. Students and academics from various Spanish universities participated in the survey.

\section{Demographics}

A total of 175 respondents took part in the survey during the given twomonth period, 132 of which were women and 43 were men. This sum is just a fraction of the total number of participants (i.e., 13.6\%). The respondents who did not complete the questionnaire were 1115 . We expected such a small percentage of complete responses before the launch of the study, judging by the relatively vast extent of the submitted data. However, the overall evaluation application provided by the application reported an average time for completion of 14 minutes.

In terms of age, we decided to divide participants into five groups that respected the human ontogenesis given by the World Health Organization (Machová, 2008): adolescence (15-18), adulthood (19-30), young age (31-45), middle age (46-60), and old age (60-100). Each development period is typical of both growth and development. From a linguistic point of view, we assume that, despite the repression of Francoist Spain, older generations will have better passive language skills, determined by a longer potential contact with other official and co-official languages, which is proportionally determined by their older age.

However, the majority age group completing the questionnaire was the second, representing the full adult age of 19-30 years, with a total of 115 participants $(66 \%)$. As for the rest, 27 of the participants $(15 \%)$ were from the young-age group; 19 (11\%) were from the middle-age group; 12 $(7 \%)$ were from the adolescence group; and 2 of them $(1 \%)$ were from the old age group.

These results are fully in line with our assumptions. As mentioned above, the questionnaire was distributed through higher-education institutions where academic staff forwarded the link of the questionnaire to their students. For this reason, we have also decided to omit the aspect of education, which is, presumably, mainly on the academic level.

The other two applied aspects, origin and residence, were chosen for two reasons. The first apparent objective was to obtain these two demographic data and compare them to each other. The second was to prevent the participation of inappropriate respondents; Catalonia, the Basque Country, Galicia, and Portugal were not included as options for choosing answers to these questions. 
Most of the respondents were from Madrid (31\% were natives, with 54 respondents, and 36\% were residents, with 63 respondents), Castilla y León (26\% were natives, with 46 respondents, and 33\% were residents, with 58 respondents), and Andalucía (18\% were natives, with 32 respondents, and $17 \%$ were residents, with 30 respondents). Other places of origin and residence did not surpass $10 \%$.

The following results are perceived as very positive: Madrid, the place of origin and residence of most respondents, is centrally located farthest from all bilingual regions and Portugal, and surrounded by monolingual regions. Castilla y León and Andalucía share the border with bilingual areas or Portugal, but no significant cultural metropolis with a bilingual language environment is in their immediate vicinity.

\section{Instrument}

We decided to use the QuestionPro web page. The questionnaire was divided into three blocks, the first consisting of detailed instructions addressed to all participants. Their primary purpose was to exclude inappropriate respondents who did not meet these requirements:

Este cuestionario acerca del bilingüismo pasivo en la península ibérica está destinado solamente a:

» los hablantes monolingües cuya lengua materna es español (castellano)

» los hablantes monolingües que viven en una región monolingüe en la cual se habla español (castellano)

» los hablantes monolingües que no entran regularmente en contacto con otras lenguas oficiales y cooficiales de la península ibérica (p.e. comunicación comercial frecuente con región bilingüe, visitas regulares y repetidas de las regiones bilingües, etc.)

Si no cumple estos tres requisitos, no rellene este cuestionario, por favor.

The purpose of this questionnaire was to find out how the speaker estimates his or her passive knowledge of the languages under examination. It would be ideal to compare the results of this self-evaluation question with the average of the results of the three complementary survey questions, but the used software did not provide such complex operations that would lead to the desired outcome.

These survey questions were asked in order to verify the estimate given by respondents when answering the first self-evaluation question. They were made to be as clear as possible, and the answers could be traced directly in the text or recording; they were not of a meta-textual 
nature. Their purpose was, in frequent cases, to determine a specific time or correctness of the claim. While creating them, we often focused on words that are not or are a little similar in Castilian.

Examples:

a) Specific time (Basque - listening)

"El hombre dice que son las 9 de la tarde.

» Correct answer: NO (Gaueko hamarrak dira. "It's 10 o'clock in the evening.")

b) Correctness of the claim (Portuguese - listening)

» João quiere convencer a Pedro de que la astrología predice el futuro.

» Correct answer: NO (De forma alguma! A astrologia só aconselha, nada prediz! "No way! Astrology gives advice and does not predict anything.")

c) Lexical differences (Catalan - listening)

» La mujer bebe té.

» Correct answer: NO (No exageri, Sra. Sugranyes, vostè pren massa cafè, per què no passa a la tisana. "Do not exaggerate, Mrs. Sugranyes, you drink a lot of coffee, why don't you have some tea instead?")

\section{Results}

In the following section, we will present the results of a linguistic nature. We will start with the dialogues read by the participants and continue with those they listened to.

\section{Reading - Galician}

Table 3. Results on reading a text in Galician

\begin{tabular}{|c|c|c|c|c|}
\hline & Understand & $\begin{array}{c}\text { Rather } \\
\text { understand }\end{array}$ & $\begin{array}{c}\text { Likely do not } \\
\text { understand }\end{array}$ & $\begin{array}{c}\text { Do not } \\
\text { understand }\end{array}$ \\
\hline Self-evaluation & $140-80 \%$ & $31-17.71 \%$ & $4-2.29 \%$ & O-O\% \\
\hline Fes & Yest question & $158-90.29 \%$ & $14-8 \%$ & Do not know \\
\hline Second question & $30-17.14 \%$ & $144-82.29 \%$ & $3-1.71 \%$ \\
\hline Third question & $38-21.71 \%$ & $129-73.71 \%$ & $1-0.57 \%$ \\
\hline
\end{tabular}

Source: Own elaboration. 
As shown in table 3 we observe that the vast majority of the interviewed respondents understand the text in Galician. A small decrease in the correct answers is observed in the third question. This is explained by a certain degree of ambiguity - some respondents could interpret it so that Helena's the father invites her on Friday for dinner and not for a dinner that will be held on Friday-as well as possible inattention when responding.

\section{Reading - Portuguese}

Table 4. Results on reading a text in Portuguese

\begin{tabular}{|c|c|c|c|c|}
\hline & Understand & $\begin{array}{c}\text { Rather } \\
\text { understand }\end{array}$ & $\begin{array}{c}\text { Likely do not } \\
\text { understand }\end{array}$ & $\begin{array}{c}\text { Do not } \\
\text { understand }\end{array}$ \\
\hline Self-evaluation & $95-54.29 \%$ & $59-33.71 \%$ & $18-10.29 \%$ & $3-1.71 \%$ \\
\hline Yes & No & Do not know \\
\hline Fecond question & $123-70.29 \%$ & $2-12 \%$ & $7-4 \%$ \\
\hline Third question & $71-40.57 \%$ & $84-48 \%$ & $31-17.71 \%$ \\
\hline
\end{tabular}

Source: Own elaboration.

As shown in table 4 we can observe that written Portuguese is understood by an overwhelming majority. The third question is the exception. As in the previous section, we are vigorously advocating for potential inattention on the part of the respondents, as the passage in which the answer to the question appears is not, in our opinion, morphologically or lexically incomprehensible to Spanish native speakers.

\section{Reading - Catalan}

Table 5. Results on reading a text in Catalan

\begin{tabular}{|c|c|c|c|c|}
\hline & Understand & $\begin{array}{c}\text { Rather } \\
\text { understand }\end{array}$ & $\begin{array}{c}\text { Likely do not } \\
\text { understand }\end{array}$ & $\begin{array}{c}\text { Do not } \\
\text { understand }\end{array}$ \\
\hline Self-evaluation & $87-49.71 \%$ & $69-39.43 \%$ & $18-10.29 \%$ & $1-0.57 \%$ \\
\hline Yes & No & Do not know \\
\hline Fecond question & $124-70.86 \%$ & $36-20.57 \%$ & $5-2.86 \%$ \\
\hline Third question & $47-26.86 \%$ & $95-54.29 \%$ & $15-8.57 \%$ \\
\hline
\end{tabular}

\section{Source: Own elaboration.}

As it is shown in table 5 the results show the greatest difference between right and wrong answers, which we again explain by the lack of the respondents' attention, as the answer to the second question is neither morpholog- 
ically nor lexically incomprehensible. The owner explicitly says that he is looking for someone who would work with a flexible schedule, and Cristina herself informs him that she can work shifts. In the third question, we assume that roughly half of the speakers did not know the term demà mateix, which is far from the Castilian mismo mañana (See appendix). We consider this part to be the least balanced within the results of reading in general.

\section{Reading - Basque}

Table 6. Results on reading a text in Basque

\begin{tabular}{|c|c|c|c|c|}
\hline Understand & $\begin{array}{c}\text { Rather } \\
\text { understand }\end{array}$ & $\begin{array}{c}\text { Likely do not } \\
\text { understand }\end{array}$ & $\begin{array}{c}\text { Do not } \\
\text { understand }\end{array}$ \\
\hline Self-evaluation & $1-0.57 \%$ & $0-0 \%$ & $17-9.71 \%$ & $157-89.71 \%$ \\
\hline Yirst question & $3-1.71 \%$ & $1-0.57 \%$ & $171-97.71 \%$ \\
\hline Second question & $5-2.86 \%$ & $2-1.14 \%$ & $168-96 \%$ \\
\hline Third question & $4-2.29 \%$ & $3-1.71 \%$ & $168-96 \%$ \\
\hline
\end{tabular}

\section{Source: Own elaboration.}

The results shown in table 6 are absolutely clear that the great typological difference between Basque and Castilian makes it impossible to understand the reading task. For a few right answers, we have several explanations: The respondents have either guessed or read the detailed instructions given at the beginning of the questionnaire distractedly and, therefore, had the active knowledge of the Basque. However, some of them could derive meaning after careful reading, as the Basque words in italics are very similar to those of Castilian (these are loans from Castilian): kotxe - coche, credit - crédito, maletan - en la maleta (See appendix).

\section{Listening - Galician}

Table 7. Results on listening a text in Galician

\begin{tabular}{|c|c|c|c|c|}
\hline & Understand & $\begin{array}{c}\text { Rather } \\
\text { understand }\end{array}$ & $\begin{array}{c}\text { Likely do not } \\
\text { understand }\end{array}$ & $\begin{array}{c}\text { Do not } \\
\text { understand }\end{array}$ \\
\hline Self-evaluation & $105-60 \%$ & $54-30.86 \%$ & $15-8.57 \%$ & $1-0.57 \%$ \\
\hline Yes & No & Do not know \\
\hline First question & $20-11.43 \%$ & $145-82.86 \%$ & $10-5.71 \%$ \\
\hline Second question & $57-32.57 \%$ & $85-48.57 \%$ & $33-18.86 \%$ \\
\hline Third question & $164-93.71 \%$ & $1-0.57 \%$ & $10-5.71 \%$ \\
\hline
\end{tabular}

Source: Own elaboration. 
Based on the presented results in table 7, we can assume that, as well as reading, the vast majority of respondents understand Galician. A significant decrease can be seen in the second question with a Galician word, which is considerably distant from the Castilian: louro in comparison with Castilian rubio.

\section{Listening - Portuguese}

Table 8. Results on listening a text in Portuguese

\begin{tabular}{|c|c|c|c|c|}
\hline & Understand & $\begin{array}{c}\text { Rather } \\
\text { understand }\end{array}$ & $\begin{array}{c}\text { Likely do not } \\
\text { understand }\end{array}$ & $\begin{array}{c}\text { Do not } \\
\text { understand }\end{array}$ \\
\hline Self-evaluation & $6-3.43 \%$ & $21-12 \%$ & $82-46.86 \%$ & $66-37.71 \%$ \\
\hline First question & $13-7.43 \%$ & $25-14.29 \%$ & Do not know \\
\hline Second question & $36-20.57 \%$ & $21-12 \%$ & $137-78.29 \%$ \\
\hline Third question & $31-17.71 \%$ & $27-15.43 \%$ & $118-67.43 \%$ \\
\hline
\end{tabular}

\section{Source: Own elaboration.}

As we expected, the specific pronunciation of Portuguese made it nearly impossible for the Spanish monolingual speakers to understand. The only exception was the word gozar ("make fun of someone"), which has a slightly different meaning in Castilian ("enjoy, look forward to"). In this case, there is a considerable shift from a relatively comprehensible reading task to a difficult and minimally understandable listening task.

\section{Listening - Catalan}

Table 9. Results on listening a text in Catalan

\begin{tabular}{|r|r|r|r|r|}
\hline & Understand & $\begin{array}{c}\text { Rather } \\
\text { understand }\end{array}$ & $\begin{array}{c}\text { Likely do not } \\
\text { understand }\end{array}$ & $\begin{array}{c}\text { Do not } \\
\text { understand }\end{array}$ \\
\hline Self-evaluation & $70-40 \%$ & $75-42.86 \%$ & $27-15.43 \%$ & $3-1.71 \%$ \\
\hline Yirst question & $9-5.14 \%$ & $144-82.29 \%$ & Do not know \\
\hline Second question & $13-7.43 \%$ & $113-64.57 \%$ & $22-12.57 \%$ \\
\hline Third question & $10-5.71 \%$ & $144-82.29 \%$ & $21-12 \%$ \\
\hline
\end{tabular}

\section{Source: Own elaboration.}

In table 9 we see far better results compared to the reading competence task in the results presented: Catalan was understood by a remarkable majority of respondents. A smaller drop is evident in the second question, in which the lexical difference between Castilian (té) and Catalan (tisana) was again used (See appendix). 


\section{Listening - Basque}

Table 10. Results on listening a text in Basque

\begin{tabular}{|c|c|c|c|c|}
\hline & Understand & $\begin{array}{c}\text { Rather } \\
\text { understand }\end{array}$ & $\begin{array}{c}\text { Likely do not } \\
\text { understand }\end{array}$ & $\begin{array}{c}\text { Do not } \\
\text { understand }\end{array}$ \\
\hline self-evaluation & $2-1.14 \%$ & $0-0 \%$ & $14-8 \%$ & $159-90.86 \%$ \\
\hline Yes & No & Do not know \\
\hline first question & $1-0.57 \%$ & $4-2.29 \%$ & $170-97.14 \%$ \\
\hline second question & $4-2.29 \%$ & $7-4 \%$ & $164-93.71 \%$ \\
\hline third question & $1-0.57 \%$ & $7-4 \%$ & $167-95.43 \%$ \\
\hline
\end{tabular}

Source: Own elaboration.

As with the previous reading task, we assume that the correct answers were either estimated by the respondents or that they had the active knowledge of the Basque language. At the same time, however, we must say that the result of listening was better than reading, which is astonishing.

\section{Discussion}

To summarize and compare the results, we used the number and percentage of correct answers for each question from each part of the questionnaire. We averaged these numbers $([\mathrm{O} 1+\mathrm{O} 2+\mathrm{O} 3] / 3)$ and then compiled the resulting order for a part of the reading and listening part. We further averaged these results $([\mathrm{N}+\mathrm{P}] / 2)$ and received a summary result containing both of the two competencies examined. These results are shown in Table 3 below.

Table 11. Summarized results of the questionnaire

\begin{tabular}{|c|c|c|c|c|c|c|c|c|c|}
\hline & reading & $\emptyset \mathbf{R}^{1}$ & ø \% & listening & $\emptyset \mathrm{R}$ & $\varpi \%$ & total & $\emptyset \mathbf{R}$ & $\emptyset \%$ \\
\hline 1 & Galician & 143.6 & 82.09 & Catalan & 133.6 & 76.38 & Galician & 137.4 & 78.56 \\
\hline 2 & Portuguese & 120 & 68.57 & Galician & 131.3 & 75.04 & Catalan & 109.6 & 62.66 \\
\hline 3 & Catalan & 85.6 & 48.95 & Portuguese & 25.3 & 14.47 & Portuguese & 72.6 & 41.52 \\
\hline 4 & Basque & 1.71 & 1.71 & Basque & 6 & 3.43 & Basque & 4.5 & 2.57 \\
\hline
\end{tabular}

\section{Source: Own elaboration.}

In the results for the reading part, we observe that most of the respondents understood only Galician (82.09\%) and Portuguese (68.57\%). In Catalan, as mentioned above, the inattention of the respondents led to only about half (48.95\%) of them understanding the written form of this language. As anticipated, success in the Basque language accounted for only a fraction $(1.71 \%)$ of the total number of participants. 
Meanwhile, the results show interesting information. Most of the respondents understood Catalan (76.38\%) and Galician (75.04\%), while Catalan, in a small difference, was more understandable than Galician. In the case of Portuguese, the already mentioned palatalization of the implosive /s/ and /z/ significantly complicated the understanding, and therefore only about $14.47 \%$ of the respondents succeeded in this part. The Basque was represented by only a minimum of correct answers (3.43\%), yet listening was slightly more comprehensible than reading.

In the last part of the table (the final results) we confirmed the hypothesis, which determined the subsequent order of languages (from the most comprehensible to the least): Galician, Catalan, Portuguese, Basque. The majority (more than 50\%) understood only Galician (78.56\%) and Catalan $(62.66 \%)$. Portuguese was successfully understood by about a third $(41.52 \%)$ of the participants. The minimum of successful respondents in the case of Basque accounts for a small fraction of the total number of participants $(2.57 \%)$.

After a detailed comparison of the results, we found that the respondents repeatedly erred in the questions that contained:

1. Any verbal expressions or vocabulary that was not similar to Castilian

2. Exact (time) data

We are fully aware that passive comprehension is based primarily on searching for similarities between L1 and the target language. Therefore, it is perfectly logical that respondents were less successful in answering questions based on unrelated vocabulary than answering questions of a general nature. These were words such as: blonde (Galician louro, Castilian rubio), tea (Catalan tisana, Castilian té), make fun of somebody (Portuguese gozar, Castilian bromear, burlarse de), right tomorrow (Catalan demà mateix, Castilian mismo mañana).

The results of the questionnaire were also largely influenced by the inattention of the respondents. This was mainly reflected in the reading task in Catalan, but also in both the reading and listening tasks in Galician. As we have already mentioned, our intention was not to confuse the respondents. We acknowledge that the answers to questions relating to the above parts may have been ambiguous to some of the participants. Nonetheless, the responses could be traced clearly in the text or the audio recording. We also consider it appropriate to specify the average time required to complete the questionnaire, which was estimated by the application tools to be 14 minutes. We believe that, during these 14 minutes, it is not possible to answer all 32 questions (4 questions per section) with care. The recording itself is a total of 4 minutes and 5 seconds (0:44 in Portuguese, 0:59 in 
Galician, 1:10 in Basque, 1:12 in Catalan), which means that the actual average time response time was somewhat about 10 minutes, i.e., 18.75 seconds per question.

On the other hand, respondents have done well with questions of a general nature that were related to the dialogue as a whole. Such questions were often answered correctly by a vast majority, which corresponds to the definitions of the passive bilingualism that underline the context comprehension as the key one.

As for the pedagogical aspects of the results, we suppose that Galician and Catalan have the potential to be used in the class as a source language since the final survey results showed that the majority understood them. From our point of view, Portuguese should be promoted more at schools in order to become more comprehensible for the student's possible future communication within the Portuguese territory, given the fact that Portugal was the only sovereign state represented by its language in the survey. Better knowledge of spoken Portuguese could also lead to a better intercultural exchange, which is, due to current lack of linguistic clarity, not so often. In terms of Basque, we presume that the typological distance cannot be surpassed easily and the only aspect we could consider to be working for possible implementation of the language at the school is the student's own motivation to master it and understand it. Nevertheless, we strongly believe that all four of them should be present in any class in a purely linguistic form; that means, for example, without any radical political ideologies included.

\section{References}

Budovičová, V. (1987). Semikomunikácia jako lingvistický problém. Studia Academica Slovaca, (16), 49-66.

Braunmüller, K. (2007). Receptive multilingualism in Northern Europe in the Middle Ages: A description of a scenario. In J. D. ten Thije, \& L. Zeevaert (Eds.), Receptive multilingualism: Linguistic analyses, language policies, and didactic concepts (pp. 25-48). Philadelphia, PA: John Benjamins.

Calvet, L. J. (1993). La sociolinguistique. Paris: Presses Universitaires de France.

Grosjean, F. (2010). Bilingual: Life and reality. Cambridge, MA: Harvard University Press.

Grosjean, F., \& Li, P. (2013). The psycholinguistics of bilingualism. Oxford: Wiley-Blackwell.

Hall, S. (2006). A identidade cultural na pós-modernidade. São Paulo, SP: DP\&A. 
Haugen, E. (1966). Semicommunication: The language gap in Scandinavia. In S. Lieberson (Eds.), Explorations in Sociolinguistics (pp. 152169). Den Haag: Mounton.

House, J., \& Rehbein, J. (2004). What is "multilingual communication"? In J. House, \& J. Rehbein, Multilingual Communication (pp. 1-18). Amsterdam: John Benjamins.

Hricsina, J. (2015). Vývoj portugalského jazyka. Praha: Karolinum.

Kloss, H. (1967). "Abstand languages" and "Ausbau languages". Anthropological Linguistics, (9/7), 29-41.

Machová, J. (2008). Biologie cloveka pro ucitele. Praha: Karolinum.

Morgensternová, M., \& Šulová L., \& Scholl L. (2011). Bilingvismus a interkulturní komunikace. Praha: Wolters Kluwer.

Ribbert, A. \& Thije, J. D. ten. (2007). Receptive multilingualism in Dutch-German intercultural team cooperation. In J. D. ten Thije \& L. Zeevaert. Receptive multilingualism: Linguistic analyses, language policies, and didactic concepts (pp. 73-102). Philadelphia, PA: John Benjamins.

Rindel-Schjerve, R. \& Vetter, E. (2007). Linguistic diversity in Habsburg Austria as a model for modern European language policy. In J. D. ten Thije, \& L. Zeevaert (Eds.), Receptive multilingualism: Linguistic analyses, language policies, and didactic concepts (pp. 49-72). Philadelphia, PA: John Benjamins.

Zeevaert, L. (2007). Receptive multilingualism: Linguistic analyses, language policies, and didactic concepts. Philadelphia, PA: John Benjamins. 


\section{Appendix}
a) Reading - Galician

\section{Questions:}

1. Helena Ilama a su padre porque necesita las Ilaves.

»Correct answer: YES

2. Helena va con sus amigos a una fiesta.

»Correct answer: $\mathrm{NO}$

3. El padre de Helena la invita para cenar el viernes.

»Correct answer: NO

\section{Dialogue:}

Padre: Diga? (Hello?)

Helena: Ola papá, son Helena. (Hey dad, it is Helena.)

Padre: Ola ruliña, como estás? (Hey honey, how are you?)

Helena: Moi ben, e ti? (Very good, and you?)

Padre: Pois ben tamén, e ti que contas? (Good as well. What are you up to?)

Helena: Pois nada, é que quería ir coas miñas amigas esta fin de semana á casa da praia e precisaba as chaves. (Nothing. I wanted to go with my friends to the cottage at the beach and I need the keys.)

Padre: Ah, moi ben. Logo ides de festa? (Ah, ok. And do you do partying later?)

Helena: Non, en plan tranquilo, imos Tere, Bego, Pili e eu, relaxarnos. (No, me, Tere, Bego, and Pili will just chill, keep it c.)

Padre: Ben, Helena. Este Xoves vou facer unha cea na casa, así que ven se queres. (Ok, Helena. I'm going to cook dinner this Thursday so come if you want to.)

Helena: Pois vale, e a que hora? (Ok then. At what time?)

Padre: Podes vir a partir das nove e media. (You can come any time after 21:30.)

Helena: Vale, grazas. Entón ata o Xoves. (Well thank you. See you on Thursday.) 


\section{b) Reading - Portuguese}

\section{Questions:}

1. Afonso está agotado e irritado.

»Correct answer: YES

2. Los dos son trabajólicos.

» Correct answer: $\mathrm{NO}$

3. Teresa duerme mucho y por eso siempre está bien dispuesta.

»Correct answer: NO

\section{Dialogue:}

Afonso: Hoje estou cansadíssimo. Creio que estou a precisar de umas férias, pelo menos um fim-de-semana fora da cidade. (I'm too tired today. I believe I need a vacation for at least one weekend away from town.)

Teresa: Tens de ter cuidado, Afonso. O médico já te disse que tens de descansar mais e abrandar o ritmo de trabalho. Além disso, tens dedicado muito pouco tempo à família desde que aceitaste esse novo cargo. (You have to be careful, Afonso. The doctor told you that you had to relax and slow down your pace at work. Besides, since you have taken up that new position, you're less dedicated to your family.)

Afonso: Olha que fala! O teu trabalho tem-te absolvido quase 24 horas por dia! (Look who is talking now! Your work absorbs you almost 24 hours a day!)

Teresa: Que exagero! Mas eu sou diferente. Posso andar deprimida durante uns días, mas depois de uma boa noite de sono fico fresca como uma alface. Tu, não. Ficas irritado, com dores de cabeça e perdes sempre o sono, o que é péssimo. (That's exaggerated! But I'm different. I can be depressed for a few days, but after one night of good sleep I am as fresh as a daisy. Not you. You are irritated, your head hurts and you cannot sleep, which is the worst.)

Afonso: Enfim! São os problemas da vida moderna. (These are, after all, the problems of modern life.) 


\section{c) Reading - Catalan}

\section{Questions:}

1. Cristina no tiene mucha experiencia.

»Correct answer: NO

2. El proprietario quiere que Cristina trabaje por turnos.

»Correct answer: $\mathrm{NO}$

3. Cristina dice que puede empezar la semana que viene.

$»$ Correct answer: NO

\section{Dialogue:}

Cristina: Bona tarda, he llegit el seu anunci i m'agradaria treballar aquí. (Good afternoon, I read your job offer and I would like to work here.)

Proprietario: Ha treballat alguna vegada en una botiga? (Have you ever worked in a store?)

Cristina: Sí, com a dependenta a la botiga de comestibles de la meva família, a Roses. (Yes, as a shop assistant in my family's grocery store.)

Proprietario: I en algun bar o restaurant? (And in any bar or restaurant?)

Cristina: També, els estius faig de cambrera. (That too. I work as a waitress in the summer.)

Proprietario: Busquem una persona que tingui mobilitat horària, perquè no sempre hi ha feina. A vegades hi ha molta gent, i a vegades, gens. (We are looking for someone who is time flexible, because the work flow is not constant. Sometimes there are a lot of people, sometimes the store is empty.)

Cristina: A mi ja em va bé. Puc treballar en règim de torns, a temps parcial o només el cap de setmana, com prefereixin. (That is good for me. I can work on shifts, half-time or just on weekends. However you prefer.)

Proprietario: I quan pot començar? (And when can you start?)

Cristina: Puc venir demà mateix. (I can come tomorrow.) 


\section{d) Reading - Basque}

\section{Questions:}

1. Xurga le recomienda a Goxo comprar la bici.

»Correct answer: NO

2. Goxo tiene una tarjeta de crédito.

»Correct answer: YES

3. La foto de la cual los dos hablan está en el maletero del coche.

$»$ Correct answer: NO

\section{Dialogue:}

Goxo: Zer triste! Kotxe hori ez da nirea! (So sad! That car is not mine!)

Xurga: Erosi kotxea. Dirua daukazu, ezta? (So buy it then. You have money, don't you?)

Goxo: Dirua galdu dut. Etxera iritsi naiz, eta poltsa hartu dut. Baina dirua ez dago poltsan. (I lost the money. I came home, got the purse and there was no money in it.)

Xurga: Badaukazu kreditu txartelik? (Do you have a credit card?)

Goxo: Bai, badaukat. Gaur ordenadorea erosi dut kredituz. (Yes, I have. I bought a computer with it today.)

Xurga: Noren kotxea ikusi duzu? (Whose car did you see?)

Goxo: Otsogizonaren kotxea ikusi dut. Otsogizonarena. Argazkia atera dut. (Werewolf's car. I took a photo of it.)

Xurga: Non dago argazkia? (Where is that photo?)

Goxo: Maletan dago. (In a suitcase.)

Xurga: Noren maletan? Norena da maleta? (In which suitcase? Whose that suitcase?)

Goxo: Nire maletan. Nirea da maleta. (In my suitcase. That suitcase is mine.)

Xurga: Beno, hartu argazkia maletatik, hartu kreditu txartela, eta erosi kotxe hori! (Ok, so get that photo out of the suitcase, take your credit card and buy that car.) 


\section{e) Listening - Galician}

\section{Questions:}

1. El hombre va andando al parque.

»Correct answer: NO

2. Al llegar al parque, el hombre ve a una pareja: una chica morena y un chico moreno.

» Correct answer: NO

3. El hombre le cuenta a la mujer sobre la broma que le había preparado su hermana Rosa.

»Correct answer: YES

\section{Dialogue:}

1: O outro día estaba tomando un café no bar que está ao lado da miña casa e o camareiro dime que teño unha chamada. Pareceume bastante raro, pero collo o teléfono e era a voz dunha moza que me di: "Temos que encontrarnos no parque, detrás da terceira árbore que hai entrando á dereita, non me falles!" (The other day I was having coffee at the bar next to my house and the waiter told me that I had a phone call. It seemed strange to me, but I answered it, and voice of a girl who said, "We have to meet at the park behind the third tree to the right by the entrance. Do not disappoint me!")

2: Oi que raro, non? (That's so weird, isn't it?)

1: Pois si, pero mira, picábame tanto a curiosidade que decidín ir, así que collín o descapotable vermello e fun para lá. Eu xa ía dicindo: "seguro que é unha rapaza que está namorada de min e tal, e que non se atreve a falar comigo", xa sabes... (Yes, but look, I was so curious that I decided to go there. I took my red convertible and drove there. I was thinking, "Surely it's a girl who's in love with me and is afraid to talk to me," you know ...)

2: Ai, claro... Como che saen mozas todos os días! (Of course. Classic girl issue.) 
1: Boh! Espera que che conto. Chego ao parque e vou ao sitio onde me dixera a moza e vexo unha parella, unha rapaza morena e un rapaz louro. Entón sento nun banco a esperar, pero a moza non vén. Así que despois de vinte minutos marcho para a casa. E cando chego á casa atopo unha nota na porta que di: feliz día dos inocentes, a túa irmá Rosa. (Just wait until I tell you what happened next. I arrived to the park and I went to the place that the girl told me to go to and I saw a couple: a dark-skinned girl and a blonde boy. So I sat on the bench and waited, but the girl was nowhere. After twenty minutes went back home. And when I came home, I found a note on the door: Happy April Fools' Day, your sister Rosa.)

\section{f) Listening - Portuguese}

\section{Questions:}

1. Pedro se está burlando de João.

»Correct answer: YES

2. Según João, la astrología casi no tiene parte subjetiva.

»Correct answer: YES

3. João quiere convencer a Pedro de que la astrología predice el futuro.

» Correct answer: NO

\section{Dialogue:}

1: Ai, que sorte. Esta semana definitivamente vou fazer sucesso. Pedro, escuta: "...e é bom que defenda os seus interesses, embora deva olhar a meios para atingir os fins." (I'm so lucky. This week I will be successful. Pedro, listen, "...and it's good that you defend your interests, although you should look for the means to secure your goals.")

2: O que é que estás a fazer, João? (What are you doing, João?)

1: Estou a ler o meu horóscopo para esta semana. (I'm reading this week's horoscope.)

2: Lá estás tu a consultar os astros. (Are you talking to the stars again?)

1: Estás sempre a gozar comigo mas olha que a astrologia é uma ciência precisa, que tem as suas regras e medidas e, embora tenha uma parte subjetiva, está é diminuta. (You are always making fun of me, but look, astrology is an exact science that has its own rules and means, and although it has subjective elements, they are tiny.) 
2: E qual é então a parte subjetiva? (And what are those subjective elements?)

1: É o papel do astrólogo na interpretação de um tema. Aí ele é intuitivo, inspirado, subjetivo e influenciador. Mas a base, o horóscopo, é um elemento matematicamente exato. (The astrologer's role in the interpretation of a topic. There he is intuitive, inspired, subjective and influencer. But the basis, the horoscope, is a mathematically exact element.)

2: Queres convencer-me de que ele pode predizer o futuro? (Do you want to convince me that he can predict the future?)

1: De forma alguma! A astrologia só aconselha, mas nada prediz. (No way! Astrology only gives advice, it doesn't predict anything.)

\section{g) Listening - Catalan}

\section{Questions:}

1. El hombre dice que hay poca gente bilingüe.

»Correct answer: $\mathrm{NO}$

2. La mujer bebe té.

» Correct answer: NO

3. Los dos creen que la lengua catalana está en crisis.

»Correct answer: NO

\section{Dialogue:}

1: Miri, Sr. Toda, la llengua catalana està en una situació difícil. (Look, Mr. Toda, Catalan is in a difficult situation.)

2: Dona, no sé què dir-li. lo no hi estic d'acord. Si tenim en compte les circumstàncies, no està tan malament. (Dona, I do not know what to tell you. I do not agree. Considering the circumstances, it is not so bad.)

1: Vostè és un optimista. (You are an optimist.)

2: Si, jo sempre penso que el vas està mig ple. (Yes, I always see the glass half full.)

1: Doncs, jo penso que està mig buit. Miri, un exemple dels problemes que tenim: el meu veí treballa amb un mallorquí $i$ diu que no l'entén i que ha de parlar en castellà amb ell. (Well, I think it is half empty. Look, one example of the problems we have: My neighbor works with a Mallorcan man and he told me he does not understand and that he has to speak in Castilian with him.) 
2: També hi ha empreses en aquest país on els empleats parlen anglès i no passa res. (Also, there are businesses in which employees only speak English and nobody is doing anything about it.)

1: I què em diu de la notícia de La Vanguardia que a la perifèria de Barcelona hi ha més gent que parla castellà que català? (And what do you say to me about the news at La Vanguardia, which says that more people speak Castilian than Catalan on the outskirts of Barcelona?)

2: Sí, però també ara hi ha més gent que és bilingüe. La majoria parla també català. (Yes, but there are more bilinguals now. Most of them also speak Catalan.)

1: I els joves? (And youngsters?)

2: Què passa ara amb els joves, Sra. Sugranyes? Vostè sempre parla malament d'ells. Ja n'hi ha prou, que no és pas tan fàcil ser jove avui dia. (What about the youngsters, Mrs. Sugranyes? You always speak badly about them. After all, it is not so easy being young nowadays.)

1: Que tots parlen castellà és el que passa, Sr. Toda, que els joves d'ara prefereixen el castellà. Jo pateixo molt per aquestes qüestions, Sr. Toda. (Everyone speaks Castilian, this is what is going on, Mr. Toda. Young people prefer Castilian now. Such questions worry me a lot, Mr. Toda.)

2: Vinga, dona vinga. No exageri, Sra. Sugranyes, vostè pren massa cafè, per què no passa a la tisana? (Come on, Dona. Do not exaggerate, Mrs. Sugranyes, you drink a lot of coffee, why don't you have some tea instead?)

\section{h) Listening Basque}

\section{Questions:}

1. El hombre dice que son las 9 de la tarde.

»Correct answer: NO

2. A los dos les gustan series criminales y policíacas.

¿Correct answer: NO

3. La mujer habla de una película con escenario muy romántico.

» Correct answer: NO 


\section{Dialogue:}

1: Gaueko hamarrak dira. Nire telesaio gogokoena ikusi nahi dut. (It's ten o'clock in the evening. I want to watch my favorite TV programme.)

2: Nolako telesaioa da? (What kind of programme is that?)

1: Oso atsegina. Bi detektibe daude. Ez dira aktoreak. Benetakoak dira. Delituei buruz hitz egiten dute. Adibidez, desfalkua deskribatzen dute, eta gero benetako kasuari buruz hitz egiten dute. Aktoreek gaiztoen paperak jokatzen dituzte. Oso interesgarria da. (A very interesting one. There are two detectives in it. Not actors, but real detectives. They talk about crimes. For example, they describe embezzlement and then talk about the real case. Actors play the role of negative characters. It's very interesting!)

2: Ez niretzat! Ez zait interesatzen horrelako telesaioa. (So definitely nothing for me. I don't like such programmes.)

1: Nolakoak gustatzen zaizkizu? (And what kind of programmes do you like, then?)

2: Beno... fi Imak gustatzen zaizkit. Gauerdian beti fi Imak daude telebistan. Gaur goizean fi Im oso polita ikusi dut. Gizon bat dibortziatu nahi izan du, bere emaztea aurkitu duelako ohean- (Well, I like movies. At midnight there are interesting movies on the TV. This morning I saw a beautiful movie. A man wanted to divorce his wife because he found her in bed-)

1: Badakit! Badakit! Beste gizonarekin! (I know! With another man!)

2: Ez, ez. Ez gizonarekin. Otsogizonarekin. Ez da gauza bera. (No, no. Not with another man. With a werewolf! And that's something completely different.)

1: Arrazoia daukazu. Ez da gauza bera! (Yes, you're right. That's not the same at all.) 
